\title{
A Remaining Hope for Durable Solutions: Local Integration of Refugees and Their Hosts in the Case of Uganda
}

\author{
Sarah Dryden-Peterson and Lucy Hovil
}

\begin{abstract}
The protracted nature of conflicts in countries of the global South means that return to home countries for many refugees is increasingly delayed. At the same time, global terrorism and concerns about security have slowed processes of resettlement in countries of the North. Local integration to host communities in countries of first asylum may be a remaining option. This paper explores possibilities for revival of local integration as a durable solution. The authors situate the study within the framework of protracted refugee situations globally and, specifically, within the existing local settlement structure and the Self Reliance Strategy (SRS) in Uganda. Benefits to refugee-hosting communities are analyzed through two case studies: local integration through commerce and through primary education. The paper concludes by exploring ways in which stakeholders, including refugees, UNHCR, and donor governments can work together to promote shared and simultaneous development in refugee and national communities, specifically in conceptualizing the $d u$ rable solution of local integration within the context of a national framework for development.
\end{abstract}

\section{Résumé}

Le fait que les conflits dans l'hémisphère Sud se prolongent interminablement signifie que pour beaucoup de réfugiés le retour dans leur pays d'origine est de plus en plus retardé. En même temps, le terrorisme global et les craintes sécuritaires ont considérablement ralenti les procédures de réinstallation dans les pays de l'hémisphère Nord. Dans ces conditions, il semblerait que l'intégration des réfugiés dans les communautés hôtes dans les premiers pays d'asile pourrait être la seule solution possible. Cet article examine donc les possibilités de raviver l'intégration locale comme solution durable. Les auteurs placent leur étude dans le cadre des situations de réfugiés qui se prolongent, et, plus particulièrement en référence à la structure locale de réinstallation qui existe déjà en $\mathrm{Ou}$ ganda, ainsi que leur 'Self Reliance Strategy' (SRS) ("stratégie autocentré»). Les avantages dont bénéficient les communautés accueillant les réfugiés sont analysés à travers deux études de cas : l'intégration locale à travers le commerce et l'intégration à travers l'éducation primaire. L'article conclut en examinant les manières par lesquelles les parties prenantes, y compris les réfugiés, l'UNHCR et les gouvernements donateurs, peuvent travailler de concert pour promouvoir le développement parallèle et simultané à la fois dans les communautés de réfugiés et dans les communautés nationales - plus spécifiquement, en conceptualisant la solution durable de l'intégration locale dans le contexte d'un plan national de développement.

\section{Introduction}

Dolitical conflicts in various parts of the world are, $\mathrm{P}$ more and more often, of an extended duration. This means that return to home countries for refugees is increasingly delayed. At the same time, global terrorism and concerns about security have slowed processes of resettlement in traditional resettlement countries and, in some cases, the number of refugees who can be resettled has fallen and their countries of origin have been restricted. The increasing size of refugee population influxes to countries of first asylum has meant that host governments have been 
reluctant to facilitate local integration; indeed, local integration carries with it a connotation of permanence as well as security problems and resource burdens. ${ }^{1}$ Failure to find acceptable durable solutions among these three options has resulted in increasing numbers of refugee situations worldwide that can be described as "protracted."

"Refugees can be regarded as being in a protracted situation when they have lived in exile for more than five years, and when they still have no immediate prospect of finding a durable solution to their plight by means of voluntary repatriation, local integration, or resettlement," ${ }^{2}$ writes Jeff Crisp. Due to the proliferation of situations that can be described as such, the many stakeholders - including host governments, the United Nations High Commissioner for Refugees (UNHCR), local communities, and refugees - need to come together to further explore the three possibilities for durable solutions and their applicability in given situations.

By the end of 2001, it was estimated that some three million refugees in Africa were in a protracted situation, ${ }^{3}$ the vast majority of them in Central and East Africa. The long-term prospect for these refugees is becoming increasingly bleak. In Africa and other parts of the global South, in particular, governments have relied on material assistance from the outside in responding to refugee situations. ${ }^{4}$ As a result, the focus of refugee assistance has been about aid, which is by nature a short-sighted endeavour. ${ }^{5}$ Over recent years, donors and other international actors have focused their attention increasingly either on high profile crises in which there are large flows of people or on large-scale repatriation cases. As a result, "[p]rotracted situations, which drag on for years and where there is no immediate prospect of a durable solution for the refugees concerned, have consequently been neglected." 6

The impact of this neglect has been felt directly by those refugees who fall into this category. Tania Kaiser describes the situation in Guinea, where reductions in food rations are taking place not because there has been a corresponding reduction in need, but because there is simply not enough assistance to go around. ${ }^{7}$ Durable solutions for refugees particularly those in protracted situations - that do not depend on continued emergency assistance are urgently needed. Crisp writes:

...the presence of so many protracted refugee situations in Africa can be linked to the fact that countries of asylum, donor states, UNHCR, and other actors have given so little attention to the solution of local integration during the past 15 years. Indeed, from the mid-1980s onwards, a consensus was forged around the notion that repatriation - normally but not necessarily on a voluntary basis - was the only viable solution to refugee problems in Africa and other low-income regions. ${ }^{8}$
Given the resulting continuation of protracted refugee situations, a reluctance in countries of the North to accept greater numbers of refugees for resettlement, and the dwindling assistance, it is imperative that local integration of refugees be explored as a durable solution. Indeed, while repatriation remains the final goal, local integration gives refugees some certainty about what to do with their lives in the meantime. Furthermore, local integration provides the possibilities of harnessing development aid for the mutual benefit of refugees and their hosts. In striving for sustainable interventions, UNHCR and donor countries are left with little option but to consider initiatives aimed at local integration.

This research explores local integration as a durable approach to the protracted refugee situation in Uganda. In Section 2, a framework for analysis of local integration is presented. Section 3 situates the study within the existing local settlement structure for refugees in Uganda and within the Self Reliance Strategy (SRS), critiquing these policies in the context of local integration. The perceived resource burden that accompanies refugees is one of the central factors that inhibits the adoption of policies that promote local integration; Section 4 therefore addresses the benefits to local communities of hosting refugees, through the specific lenses of integration in primary education and in commerce. In conclusion, Section 5 explores ways in which stakeholders can work together to promote shared and simultaneous development in refugee and national communities, specifically in conceptualizing the durable solution of local integration within the context of a national framework for development, in this case the Poverty Eradication Action Plan (PEAP).

\section{Local Integration as a Durable Solution}

\subsection{Local Integration: A Framework for Analysis}

Rhetorically, integration has always been a guiding principle of refugee programs in countries of the global South. According to the 1951 UN Refugee Convention, restoring refugees to dignity and ensuring the provision of human rights includes an approach that would lead to their integration in the host society. ${ }^{9}$ Indeed the Convention uses the word "assimilation," which implies the disappearance of differences between refugees and their hosts as well as permanence within the host society. ${ }^{10}$ Recent thinking, however, emphasizes both the importance of maintaining individual identity ${ }^{11}$ and the possibility of "promoting selfreliance pending voluntary return,"12 whereby local integration could be temporary. ${ }^{13}$

The possibility of integration of refugees and their hosts is a question of concern for the international community and host governments, especially in the context of protracted refugee situations. While the impact of refugees on 
host populations has been explored at a theoretical level, ${ }^{14}$ there has been little academic research on the costs and benefits of refugee presence to host populations in a country-specific context. ${ }^{15}$ In addition, methods to quantify levels of integration between refugee and host communities are lacking in the literature. Indeed, disagreement over the mere definition of the word "integration" in immigration contexts worldwide, and specifically in refugee situations in countries of first asylum, makes analysis of this topic difficult and has prevented adequate research. ${ }^{16}$

Barbara Harrell-Bond outlines a simple definition of integration in a refugee context that is useful to employ as a guide for the purposes of this discussion: "a situation in which host and refugee communities are able to co-exist, sharing the same resources - both economic and social with no greater mutual conflict than that which exists within the host community." ${ }^{17}$ Tom Kuhlman makes this definition more explicit in outlining indices that can be used to gauge refugee integration to a host community. Among others, he identifies the following characteristics of successful integration:

- the socio-cultural change they undergo permits them to maintain an identity of their own and to adjust psychologically to their new situation

- friction between host populations and refugees is not worse than within the host population itself

- refugees do not encounter more discrimination than exists between groups previously settled within the host society. ${ }^{18}$ The economic and social factors of integration embodied in these definitions of integration are crucial to the examination of policies that foster or prevent local integration. Indeed, as will be demonstrated in the case of Uganda, often the mere structural integration of services is seen as a substitute for the more complex process of local integration.

\subsection{Local Integration in Countries of the Global South}

In countries of the global South, areas that host refugees are themselves plagued with poverty, characterized by a lack of resources and infrastructure for social services and by corresponding difficulties in accessing economic markets. In this context, analysis of the costs and benefits of local integration to host communities are critical in policy formation. As Kibreab asks,

Given the severity of the economic crises and the environmental degradation facing many of the major African refugee hosting countries, the basic issue that emerges is, can these countries be able or be expected to establish policies, legal frameworks and institutions which could allow the absorption of hundreds of thousands of refugees living within their territories into their societies permanently? ${ }^{19}$
Kibreab then argues that in fact host governments in Africa could not be expected to carry this burden, and he proposes local settlement structures - spatially segregated sites that could be supported by international donors - as the optimal solution. Many countries, of which Uganda is one, have adopted this strategy.

More recent literature, however, suggests that the benefits to host communities of hosting refugees can outweigh the costs, if structures are set up in such a way as to promote joint development. ${ }^{20}$ This paper aims to contribute to this body of literature through an examination of the benefits of local integration to refugee-hosting communities, using education and commerce as case studies.

\section{Local Integration as a Durable Solution in Uganda}

While Uganda has historically dealt with numerous prolonged refugee situations, the previous decade has seen a greater influx of refugees than at any time in the past. As of December 2002, the UNHCR reported a national total of 197,082 refugees living in Uganda, primarily from Sudan, Democratic Republic of Congo (DRC), and Rwanda. ${ }^{21}$ It is important to note, however, that this number represents the refugees who are registered with UNHCR and who, almost exclusively, live in settlement areas. In addition to this number, conservative estimates place the number of self-settled refugees in the country at approximately 50,000. In reality, the number is probably far higher. Furthermore, there are 10,000 refugees registered with the Office of the Prime Minister as self-sufficient urban refugees ${ }^{22}$ and it is estimated that 5,000 to 10,000 others live in Kampala without assistance or protection. ${ }^{23}$

Uganda provides a unique context for the investigation of local integration as a durable solution. ${ }^{24}$ It has a long history as both a generator of refugees and a host country for refugees, ${ }^{25}$ and the integration of refugees into Ugandan society has been a common occurrence. As Abraham Kiapi writes, "[u]nless in the case of influx, refugees are, in practice, integrated into Ugandan society. They have been offered employment, including joining the police force and even the army."26 While social, economic, and cultural integration of refugees to Uganda has successfully occurred in the past, the difficulty of political integration has been a common factor in all cases. ${ }^{27}$ Indeed, the legal structures of Uganda have shaped, and continue to shape, the possibilities for local integration in this country.

\subsection{The Impact of Legal Structures on Local Integration}

The current legislation relating to refugees in Uganda is the outdated Control of Alien Refugees Act (CARA). Enacted in 1960, eighteen years before Uganda ratified the 1951 Refugee 
Convention, the CARA is inconsistent with international standards relating to the treatment of refugees. As its title implies, the act focuses on the control of refugees. Although the Act has never been strictly applied in Uganda ${ }^{28}$ this emphasis has had an impact on how refugees are treated. It regulates, for instance, the way in which assistance is delivered to refugees: aid is contingent upon a refugee living in a designated settlement, all of which are located in rural and isolated areas of Uganda. The only exception to this regulation is the 180 refugees $^{29}$ who are recognized on UNHCR's urban caseload. ${ }^{30}$

In addition to those refugees who have been officially recognized by the Government of Uganda (GoU) and the UNHCR and are living in settlements, there are tens of thousand $s^{31}$ more who do not live in settlements. They have opted out of the assistance structures and, instead, have self-settled among the Ugandan population. While "official" refugees fall under the control of the national government structures (through the Directorate of Refugees, Office of the Prime Minister), self-settled refugees tend to operate within the local government structures, both rural and urban. They are integrated into their host community, pay graduated tax, contribute to the local economy, and even run in local council elections. ${ }^{32}$ However, their legal status remains insecure and ambiguous: they fall within the category of prima facie refugees, but are in danger of being seen as illegal immigrants.

\subsection{Local Settlement Structure for Refugees in Uganda}

As stated above, Uganda historically has hosted refugees in local settlements. In northern Uganda, the local settlement program for Sudanese refugees started in 1992, when land was made available for agricultural production. ${ }^{33}$ Settlements are large, isolated areas of land located in rural areas of Uganda, the greatest concentration being in the northwestern region. These settlements are, in theory, supposed to offer a more permanent departure from the temporary "transit camp." ${ }^{34}$ Policy makers state that the original objective of the local settlement policy was to promote a degree of self-sufficiency for refugees. ${ }^{35}$ In real terms, this has meant little more than making small plots of land available for the refugees to use, within the geographical confines of the settlement. ${ }^{36}$ However, the location of the settlements, the lack of sufficient arable land, and the general insecurity that has characterized northern Uganda for decades have compromised attempts at self-sufficiency in most $_{\text {cases. }}{ }^{37}$

Self-sufficiency has been further hindered by lack of freedom of movement, imposing restrictions that conspire against refugees becoming economically and socially independent. In order to leave the settlement in which they reside, refugees must obtain a permit issued by the Settlement Commandant, which is a time-consuming and unpredictable process. A recent study in Kyangwali settlement, western Uganda, showed the extent to which self-sufficiency is compromised by restrictions on movement - as well as corresponding limitations on employment - which exclude refugees from basic interaction with external goods and labour markets. ${ }^{38}$ Likewise in Moyo settlement, refugees are isolated not only as a result of the bureaucratic restrictions placed on them, but by the fact that they often do not have the resources to travel the large distances between the settlements and surrounding markets. ${ }^{39}$

As well as creating economic isolation, the settlement structure also generates social seclusion. The physical separation between refugees and nationals creates an environment conducive to tensions between the two groups. For instance Ugandan nationals often perceive refugees as being better off than they are, as they witness World Food Programme (WFP) trucks moving into the settlements. They are also seen as a source of potential competition over scarce resources such as firewood and boreholes. ${ }^{40}$ This is due, in part, to the fact that districts within which settlements are located are themselves underserved and marginalized. In addition, although services such as primary schools that have been created for refugees are, in theory, shared with the surrounding national population, there has been a lack of coordination between refugee assistance structures and the wider district development structures, creating inefficiency and exacerbating tensions.

\subsection{Self-Reliance Strategy}

By the late 1990s, policy makers were increasingly looking for a more sustainable solution to the protracted refugee situation in Uganda. At the same time, the need to operate in coordination with the wider service-delivery structure of Uganda "to optimize [sic] the use of resources for the good of both refugees and the host community" ${ }^{41}$ was being recognized. The result was the creation of the Self Reliance Strategy (SRS).

The SRS was jointly designed by the Office of the Prime Minister (OPM) and UNHCR Uganda in May 1999, the culmination of a process that officially began in 1998. It was conceptualized specifically for Sudanese refugees living in the West Nile districts of Arua, Adjumani, and Moyo, recognizing the long-term nature of their situation. ${ }^{42}$ Its overarching goal, as stated, is "to integrate the services provided to the refugees into regular government structures and policies" 43 and, in so doing, to move "from relief to development." ${ }^{44}$ As Dorothy Jobolingo, Education Advisor to UNHCR Uganda states, "[w]e cannot treat it as a relief situation where we give them something to eat every 
day. That is not a durable solution....... The SRS is not theory. It is a practical solution." ${ }^{\prime 4}$

In order to bring about a change from relief to development, the SRS emphasizes the dual objectives of empowerment and integration, in order "to improve the standard of living of the people in Moyo, Arua and Adjumani districts, including the refugees." ${ }^{46}$ It seeks to give refugees the ability "to stand on their own and build their self-esteem" through gaining skills and knowledge to both take back to their home countries when they return, and to leave behind sustainable structures. ${ }^{47}$ At the time it was written, it was envisaged that, by 2003, refugees would be able to grow or buy their own food, access and pay for basic services, and maintain self-sustaining community structures. The SRS was designed to be implemented at a district level, with OPM and UNHCR playing coordinating roles, and "[ensuring] harmonisation of policy." 48

In order to "empower refugees and nationals...to the extent that they will be able to support themselves," ${ }^{49}$ the SRS outlines the integration of service delivery in the sectors of agricultural production, income generation, community services, health and nutrition, education, water and sanitation, the environment, and infrastructure development. In this way, it addresses one flaw of the local settlement policy, that of parallel service delivery. It does not, however, address many of the other shortcomings. Indeed, it embraces one of the fundamental problems with traditional development: it attempts to substitute the provision of services for sustainable development based on economic growth. ${ }^{50}$

\subsection{Self-Reliance in the Context of the Local Settlement Structure}

While the SRS provides a framework for addressing the protracted refugee situation in Uganda, it contains fundamental flaws. The policy itself acknowledges that the success of the SRS is contingent upon two factors: first, that the SRS should be implemented under a new Refugee Bill that addresses such issues as freedom of movement, taxation, trade and employment opportunities, and temporary access to land; second, that it should operate in an environment that is secure from armed conflict. ${ }^{51}$ To date, neither of these factors has been resolved: Uganda has, thus far, failed to pass new refugee legislation, and refugees and surrounding populations continue to be attacked by rebel groups, most notably the Lords Resistance Army (LRA). ${ }^{52}$ In addition to these two factors, the SRS also acknowledges the marginalization of the West Nile region as being a further limiting factor.

While the SRS acknowledges these factors, there are other flaws within it that have not been taken into consideration. In particular, the SRS advocates self-reliance with- out local integration. Integration, as defined by the SRS, is based primarily on the coordination of services; it does not present social and economic integration as a necessity in such a process. By divorcing the two areas - integration of services and social integration - rather than acknowledging that they are mutually dependent, the SRS ensures that it cannot bring about self-reliance. Furthermore, while the word "communities" in the SRS document is used to refer to refugees and hosts collectively - reflecting an emphasis on a "community-based" approach - the term, in reality, refers to two geographically isolated groups. The notion of "community" in this context is anathema.

While the SRS expresses similarities between refugees and hosts in terms of cultural background and refers to their common experience of refugeehood, it keeps them physically segregated through the local settlement structure. The concept of full integration - in other words the abolishment of the settlement structure - is left hanging: "Finally, the freedom of movement for refugees within Uganda should be as broad as possible, although a reasonable system of control should not be rejected out of hand." ${ }^{53}$ Thus, as with the local settlement structure, the sticking point continues to be the issue of freedom of movement; ${ }^{54}$ the SRS attempts to propagate a free-market economy, whereby self-reliance could be achieved, but within a command economy framework. As illustrated below, the impact of these restrictions on commercial activity is just one example of the limitations imposed by such a contradictory approach.

In addition, the SRS refers only to refugees who are in the official assistance structures, and makes no more than a passing statistical reference to the many self-settled refugees living in Uganda. This is a serious omission for two reasons. First, it fails to reflect the refugee population in its entirety. Second, and most importantly, it misses the opportunity to learn from refugees who have, themselves, gone some way towards reaching the dual goals of empowerment and integration laid out in the SRS, not least through commercial enterprise and participating in local labour markets.

\subsection{Implementation of the Self-Reliance Strategy}

The time frame for implementing the SRS, as outlined in the original Strategy Paper published in May 1999, was ambitious. It envisioned a four-year implementation process, with " $[\mathrm{t}]$ he last two years of the strategy...used to consolidate the structures and systems established in the first two years." ${ }^{55}$ The one specific benchmark stated was that "[f]ree food distribution will be ended by July 2001," 56 as the first real step in self-sufficiency. Despite these plans, the implementation of the SRS has been slow and disorganized. 
Problems associated with the implementation of the SRS have a number of origins. First, the Refugee Bill that was expected to be passed into law by 2001 at the latest ${ }^{57}$ still remains in Parliament where is has just received its first reading. Second, the reluctance of donors to include refugees in district development plans has constrained plans for implementing the SRS effectively. ${ }^{58}$ Indeed, development aid to Ugandan nationals and international assistance to refugees continue to be separate and parallel processes. Third, and most importantly, administrative failure and lack of communication have consistently led to delays and misunderstandings in the implementation process. There is disagreement, in fact, over when the implementation of the SRS actually began. A UNHCR representative cites a 2001 start date, when money started to change over to district levels. ${ }^{59}$ An official from the Office of the Prime Minister is explicit that it was not until January 2002 that the SRS took effect. ${ }^{60}$ District Education Officers and Camp Commandants outside of the West Nile region do not know if the SRS has yet taken effect in their areas and if they are responsible for implementing it. ${ }^{61}$ What is clear, however, is that implementation of the SRS has not gone according to plan.

In the sphere of education, it was not until February of 2001 that a workshop was convened to "start looking at the possibilities for integration from a technical point of view and to aim at the hand over of education service delivery from Implementing Partners (IP's) to local governments in the most efficient way." ${ }^{2} 2$ Education was not the first sector to be integrated. Indeed, a similar delay was experienced in other sectors and, more importantly, processes of "sensitis[ing] communities (Nationals/Refugees) in districts on integration," ${ }^{63}$ a process that the designers of the SRS indicated would be crucial to the SRS implementation from the outset, ${ }^{64}$ had not yet begun by February $2001 .{ }^{65}$ This sensitizing and coordination of stakeholders is a problem that persists to the present. The only person at the Ministry of Education and Sports with even partial responsibility for refugee education says, " $\mathrm{t}]$ here is very little written communication. We go to these [refugee-hosting] schools, we see libraries and classrooms, organisations have given physical cash. But there is no written communication about what they are doing to their schools. So that limits knowledge." ${ }^{66}$ It also limits the possibilities for a true integration of services, let alone of communities.

\subsection{Review and Evaluation of the Self-Reliance Strategy}

The UNHCR and the Government of Uganda had planned a review and evaluation of the SRS during the year 2002. Due to ongoing violence in the West Nile region, however, the lives of refugees have been severely disrupted. Linnie Kes- selly of UNHCR Uganda explains that while refugees in Adjumani, for example, had become self-sufficient in terms of food production, the upheavals of recent attacks and violence have caused refugees to flee their fields and become once again dependent on direct assistance. An evaluation in this context would not be productive, she said. ${ }^{67}$

An exhaustive critique of the Self Reliance Strategy is outside the scope of this paper. As outlined above, however, critical aspects of the process of integration have been overlooked both in the formation of the SRS policy and in its implementation. As a result, the possibilities for local integration as a durable solution are not being fully explored at a policy level, within the Ugandan context. Indeed, the Self Reliance Strategy has been conceived and operationalized in isolation from direct experiences with the process of integration of refugee and national communities.

\section{Benefits to Host Communities in the Case of Local Integration}

In this section, the paper seeks to illuminate some of the factors that are essential to successful local integration of refugees in Uganda through two case studies. The first case study examines refugee engagement in commerce from both within the settlement structure and in a self-settled context. This engagement does not take place according to a planned policy but is rather a strategy spontaneously employed by both refugees and nationals as a means of sustaining livelihoods. The second case study analyzes the service-delivery aspect of primary education as well as the day-to-day realities of social integration through teaching and learning. This social integration takes place both as part of a planned policy and through self-directed local efforts to provide quality education, often seen as "the key to the future." 68

The two case studies have been chosen to demonstrate the limitations of local integration within the current Ugandan context and to explore and outline the possibilities for success. They examine situations in which the social integration of refugees and hosts takes place at different levels to provide important models both of the processes of social integration under differing conditions and the benefits to refugees and their hosts of such integration. It is work that the authors believe should have been undertaken in the process of development of the SRS and that we believe to be a necessary framework for an urgently needed review and evaluation of the SRS in particular and of local integration as a general principle.

\subsection{Economic Integration through Commerce in Moyo District}

Commerce is a sector that is fundamentally linked to issues of self-reliance and integration, and illustrates many of the 
issues outlined above. Field research in Moyo district in the West Nile region of Uganda ${ }^{69}$ provides a telling example of the interaction between commerce and integration. Moyo district lies in Uganda's West Nile region, with the White Nile along the southern border flowing to the northeast, and the border with Sudan to the north. Moyo town is the administrative headquarters for the district and lies fifteen kilometres south of the border with Sudan. The district is in a semi-arid area and has experienced increasingly sporadic rainfall since 1998, creating a harsh agricultural environment and low standards of living. It is also host to approximately 23,000 registered refugees living in the Palorinya Refugee Settlement cluster, and an unknown number of self-settled refugees living throughout the district, but with greater concentration in Moyo town and along the Sudan border. Within the settlements, the SRS has been partially implemented, and some refugees are no longer receiving any assistance.

Through interviews with a cross-section of settlement and self-settled refugees, as well as nationals and officials living in the district, there was an observable difference between the economic activities of settlement refugees and those of self-settled refugees. At one level this is inevitable: self-settled refugees, having opted out of the assistance structures, are forced to find alternative means of survival. However, the difference appeared to go deeper than necessity, and related to the wider socio-political context. Indeed, the function of commerce within this context is tied inextricably to issues surrounding policies on refugee protection, specifically the emphasis on the settlement policy.

Settlements, which are, by their very nature, closed spaces, place serious limitations on commercial activity. For any commercial venture to succeed, goods need to move, and people need to trade and move to places where commercial returns are optimal. In other words, for settlement refugees to engage in commercial activity with any degree of success, they need to be able to leave the settlement with their produce and find a suitable market. Furthermore, they need to be able to do this without jeopardizing their status as refugees. However, our findings indicate that the restrictions placed on settlement refugees are preventing this from happening at any commercially viable level. Eric Werker, in a study carried out in Kyangwali settlement in western Uganda, highlights three restrictions placed on the economic freedoms of refugees: bureaucratic and insecurity-related limitations on movement that prevent refugees from moving in and out of the settlement freely, limitations on working that effectively exclude refugees from external labour markets, and the lack of transport and information flows to and from the settlement. ${ }^{70}$ The same restrictions apply directly to Palorinya settlement: with the presupposition for effective commerce being linked to movement, the fact that settlement refugees have their movement so seriously restricted means that they are unable to move freely to markets. Furthermore, should they wish to, they are unable to move to another location where there might be better markets and a wider job market and where their skills are in greater demand.

This lack of ability to carry out commercial activity is accentuated by the fact that many settlement refugees both those under the SRS and those who are receiving full assistance - showed both a desire and a need to generate additional income. For instance, the most common complaint made by the settlement refugees was that they were unable to generate the funds to send their children to secondary school. While primary education is free, refugees and nationals alike have to pay for secondary education, a demand that is all but impossible for settlement refugees who are unable to generate additional income. Furthermore, the lack of economic opportunity has created an environment of helplessness and dependency - well-documented throughout the literature - that further conspires against what little available commercial activity there is in such a closed, harsh environment.

Self-settled refugees, on the other hand, presented an alternative, even diametrically opposed, picture of commercial activity. These refugees had deliberately opted out of the settlement structure, often because they saw the commercial advantages of doing so, even though it meant they did not receive basic allocations of food, non-food items, and land. Instead of receiving handouts or trying to farm small parcels of inadequate land, they were engaging in a wide variety of commercial activities throughout the district. One young boy talked of how he went into Sudan during the mango season to pick mangoes that he would then sell in local markets within Moyo. By doing this, he generated enough income to pay his school fees. ${ }^{71}$

While this example clearly contravenes tidy, international standards, it is pertinent to note that his activities were taking place with the endorsement of local government officials. Interviews with such officials showed the extent to which they recognized the advantages of allowing refugees to interact freely within the economic activities of the district, not least because it has widened their tax base and increased local revenue. While there was a clear proviso that refugees had to follow the rules that applied throughout the district, local government officials showed the extent to which they had recognised the potential benefits of allowing refugees to engage freely in commercial activity.

However, while the outlook for many self-settled refugees was positive, particularly in contrast to the dependence and helplessness of settlement refugees, it is important not to over-romanticize their situation. Indeed, for many, life 
was a daily challenge of survival in a difficult environment, exacerbated by a national policy that prevents self-settled refugees from receiving any additional help outside of the settlement. Furthermore, interviews revealed three potential pitfalls that need to be kept in mind. First, when refugees have become successful in business, politicians have been known to draw attention to disparities between refugees and nationals, thus generating xenophobia. Second, a number of refugees were perceived by nationals to have abused their commercial success with similar results. Finally, when rains fail or the local economy takes a downturn, it is often the refugees who are first to suffer though loss of jobs and increased vulnerability.

Even acknowledging such considerations, it is clear that commercial activity offers a gateway for local integration to take place - not only in allowing refugees to carry out activities with which they are familiar and to improve their standard of living, but also in benefiting the host communities through increased economic activity and local revenue. However, the basic requirement of commercial activity is freedom of movement and choice. Even with the implementation of the SRS, which is supposed to encourage refugees to take more responsibility for their own lives, the limitations on their freedom of movement continually conspire against commercial enterprise. There is thus stagnation within the settlements. Despite the many difficulties they also face, the self-settled refugees show a clear alternative that allows for creativity and self-respect. Furthermore, the fact that self-settled refugees are operating within the local government structures gives their commercial activities security and sustainability.

\subsection{Social Integration through Primary Education in Kyenjojo District}

While the issues of freedom of movement and integration of refugees and nationals through commerce are skirted by the SRS, education is a sector that is explicitly addressed in the design and implementation of the SRS policy. In particular, the SRS advocates "integrating refugee primary and secondary schools into the district education system." ${ }^{72}$ In so doing, the SRS aims to develop "mechanisms for the inclusion of the refugees into the Universal Primary Education (UPE) being implemented in Uganda"73 and to ensure that "the conditional grants provided to the districts for UPE...be increased to include refugees." ${ }^{74}$ Under this system, schools would receive an allocation of UPE funds from the Ugandan government for all pupils, regardless of whether they are refugees or nationals, in addition to funds provided by the UNHCR designed to specifically target refugee education. In this way, both service-delivery and funding for education of nationals and refugees is to be coordinated. Not all refugee-hosting schools in Uganda, however, are included in these initiatives of the SRS.

In the sphere of education, the case is considered of a refugee-hosting area, Kyenjojo District, in which both the integration of services and social integration are taking place. The site is not one of those included in the SRS; the integration occurs simply through coordination between district officials and UNHCR and its implementing partners. While this site is located within the local settlement structure, it is a settlement that is secure, where there is greater freedom of movement than in other places, and where there is open economic interaction between refugees and nationals. This case seems to have been overlooked in the development of the SRS and yet it holds important lessons in the search for models of local integration for refugees in Uganda.

Kyaka II Refugee Settlement is located in Kyenjojo District in Western Uganda on eighty-one square kilometres of land ${ }^{75}$ approximately seventy kilometres by road from the town of Mubende. At the end of December 2002, 3,159 refugees were living in Kyaka II, including 1,905 Rwandese, 1,242 Congolese, and 12 Kenyans. Fifty per cent of the refugees are male, 50 are female. ${ }^{76}$ The Kyaka area first hosted refugees in the 1950s following the political turmoil in Rwanda that led to the flight of thousands of Batutsi into Uganda. ${ }^{77}$ Kyaka II was created as a settlement to host these refugees in 1959, and many of them stayed until 1994 when it became safe to return to Rwanda. ${ }^{78}$ Since 1994, Kyaka II has hosted primarily Congolese refugees and Rwandese of Bahutu origin.

Although Kyaka II refugee settlement was not included in the conceptualization of the SRS, the abundance of land and the stability of surrounding national communities have been conducive to the integration of services in this settlement. Indeed, it meets the conditions for successfully establishing self-reliant communities, as outlined in the SRS. While schools in Kyaka II have received and continue to receive assistance from UNHCR, "they are like any other schools because to us those schools are also government schools."79 Indeed, refugee pupils are counted in the overall population of a school, and UPE funds are granted on the basis of those numbers; ${ }^{80}$ UNHCR supplements the amount the school receives with school fees paid for each refugee child. ${ }^{81}$ As the District Education Officer (DEO) for Kyenjojo says, "I grew up and found that these people are studying together.... [T] here is no way you can say that refugees go there [points one direction] and those who are not refugees go there [points in the other direction].... [T] he goal is to have the child educated. So we don't separate them." 82

Bujubuli Primary School opened in 1984 and has, since that time, served both the refugees and the nationals who 
have made their home in the area. In April 2003, there were 160 refugee and 177 national pupils at this school. A sense of co-operation among pupils and teachers pervades the school. The school feels peaceful; it does not feel like a conflict or displacement situation. It is located far from insecure borders and there is enough land for people to grow their own food. It is a stable place for refugee children. ${ }^{83}$

The social integration of pupils at Bujubuli Primary School is obvious. On a symbolic level, this integration is demonstrated by the two flags that fly in front of the school: the Ugandan national flag and the flag of the Batooro people. ${ }^{84}$ At afternoon parades, the children sing the Ugandan anthem, the Ugandan school anthem, and the anthem of the Toro Kingdom. There is a sense that all of the children of the school are "young women and men of Uganda... uniting for a better Uganda." ${ }^{85}$ Further, there is not a sense of children being asked to give up their identities as Rwandese or Congolese; but there is a sense of equal belonging. On an individual level, refugee and national pupils model social integration as they do not all sit together in groups but mix in class, by their own choice. ${ }^{86}$

The majority of pupils at Bujubuli are nationals. Although the school was originally built by UNHCR with the aim of providing education for refugees, the nationals who make their home in the area have also benefited. First, children state in interviews that if Bujubuli Primary School were not there, they would have to walk many kilometres to go to the nearest school and may, in fact, not attend school. ${ }^{87}$ In this way, access to primary education for nationals is augmented by the presence of refugees. Second, Bujubuli feels more stable than other schools due to the continued presence, aid, and supervision of both UNHCR - and its implementing partner, Office of the Prime Minister (OPM) - and district education officials, which is a benefit to refugees and nationals alike. ${ }^{88}$ Third, the infrastructure that has developed with the financial support of both of these stakeholders is more substantial than in neighbouring schools and thus promotes the standard of education for both refugees and nationals. Fourth, the teaching force of the school is almost entirely national, with only one refugee teacher. These nationals are paid both by the Ministry of Education and Sport (Government of Uganda) and the UNHCR, through OPM. The presence of refugees in this area thus increases opportunities for employment of local teachers. Lastly, due to the population of refugee pupils, teachers are hired both by the MOES and OPM, resulting in a greater number of teachers than would otherwise be posted at the school. The lower pupil-toteacher ratios allow for greater interaction between pupils and teachers, more frequent marking of books, and increased class participation by individual pupils, ${ }^{89}$ thus serv- ing to increase the quality of education available in this area of Uganda.

\section{Conclusions: Local Integration within a Model of Development}

The case studies of commerce and education in Uganda demonstrate the need for policies, and their implementation, that strive for joint development among refugees and their hosts. In this context, the simple integration of services cannot be substituted for careful planning, coordination, and monitoring of the social and economic integration of these communities. In order to achieve benefits for both refugees and hosts, conceptualizing local integration through a model of development is essential.

\subsection{A Framework for Development: The Poverty Elimination Action Plan (PEAP)}

The Poverty Eradication Action Plan (PEAP) is the framework that guides development for Ugandan nationals in Uganda. It articulates a national vision to eradicate mass poverty in Uganda by 2017. Specifically, the goal is to reduce the number of people living below the poverty line to 10 per cent by that time - from 56 per cent in 1992-93, and 35 per cent in $2000 .{ }^{90}$ Since its inception in 1997 , it has guided the formulation of government policy as well as the direction of international aid. Indeed, the PEAP is the overarching national planning document of the Government of Uganda and clearly places poverty eradication as the fundamental goal of the Government. ${ }^{91}$

As put forth through this document, development is measured by the eradication of poverty that, it argues, will only be possible with economic growth. From these basic assumptions stem the four major, and interrelated, goals of the PEAP: first, rapid and sustainable economic growth and structural transformation; second, good governance and security; third, increased ability of the poor to raise their incomes; and last, increased quality of life of the poor. ${ }^{92}$

Goal 1 expresses the need for large-scale economic growth as a means to eradicate poverty; this growth, while it aims to be rapid, also needs to be sustainable. The PEAP simultaneously advocates for structural transformation within the Ugandan economy, specifically in the context of agriculture. Indeed, the basis of poverty in Uganda is the "poor economy where most people are locked into traditional subsistence agriculture." ${ }^{93}$ Importantly, however, the PEAP asserts that the transformation of the economy from agriculture to non-agricultural sectors must happen through the modernization of agriculture and not by its abandonment.

Goal 2 underlines the essential conditions that must be present for development to occur: good governance and 
security. When consulted, ordinary citizens "see a definite and direct link between insecurity and poverty levels. For example they say whole regions (North East and Karamoja) have lagged behind in terms of development largely due to prolonged insecurity. ${ }^{94}$ Development simply cannot happen without security of person and property.

Goal 3 is the projected outcome of the economic growth described above: an increase in the ability of the poor to raise their incomes. In order for people to raise their incomes, development strategies need to find ways that the poor can participate in economic growth. It is only through this participation that they can benefit. The idea of the PEAP, and the thrust of Goal 3, is not that the rural poor serve as beneficiaries of the country's economic growth but that they are engaged in that growth.

Goal 4 is the anticipated result of the previous three goals. The aim is that with economic growth and the ability of the poor to raise their incomes, the poor will experience enhanced quality of life. Although increased quality of life is dependent on greater access to services such as education and health care, the PEAP is clear that, alone, provision of services is not development. It presents the role of provision of these public services only as a subsidiary to the economic growth that comes with individual freedoms and development of human agency. Creating the environment in which individuals can ensure their own access to services, it argues, is more important than the direct provision of those services.

At its most fundamental level, the PEAP represents a blueprint for long-term national development within the context of a stable environment. It recognizes the need for security, and underscores the extent to which the provision of services is not, in itself, development. ${ }^{95}$ The creation of local integration of refugees as a durable solution - a move from relief to development - as outlined in the SRS, needs to take place within the framework created by the PEAP for development in Uganda.

\subsection{Towards Local Integration of Refugees in Uganda}

Assistance to refugees in Uganda needs to be considered in the light of the PEAP. The question that needs to be asked is, how does development - as set out in the PEAP - occur in the context of the local settlement structure? The local settlement structure and the PEAP present two parallel and uncoordinated assistance/development structures - one for refugees and the other for Ugandan nationals. Perhaps the question is then better phrased as, can development occur in the context of a local settlement structure? Self-sufficiency and local integration operate in a symbiotic relationship. Economically, politically, and socially, it is not possible to have one without the other. The SRS system proposes harmony through the integration of services, yet it lays the foundation for antagonism by maintaining notions of "otherness" inherent in the settlement structure.

As evident in the case studies of commerce and education, Ugandan policy needs to shift in order to realize the full mutual benefits of local integration for refugees and their hosts. While this responsibility rests with the host government, the international community, especially an active donor community, has a fundamental role to play. Indeed, the great reluctance of host governments such as Uganda to adopt policies that could promote the self-reliance of refugees rests in the perceived lack of economic viability of this possibility. Specifically, within the confines of a settlement structure, international assistance targeted to refugees can be easily channelled to that purpose; conversely, and importantly, development aid targeted to national populations reaches national populations and does not become diluted by an additional refugee population. In a country of extreme poverty and lack of infrastructure and in which development aid accounts for 52 per cent of the operating budget, the possibility of losing international aid to refugees through an integrated approach is perhaps a risk not worth taking. Until the point at which donors include refugees in development plans and fund district plans accordingly, there will be a continued disincentive for a change in Ugandan refugee policy.

Joint development of refugees and their hosts through a model of local integration is a remaining hope for durable solutions. Indeed, it may be the only remaining option for most of the world's refugees, as possibilities for repatriation and resettlement become slim in areas of protracted conflict and tightening of borders in countries of the North. As demonstrated in this paper, however, local integration need not be conceived of as a fallback option, but instead as a positive step in securing long-term stability for both refugees and host communities.

\section{Notes}

1. Karen Jacobsen, "The Forgotten Solution: Local Integration for Refugees in Developing Countries," New Issues in Refugee Research, Working Paper No. 45 (Geneva: UNHCR, July 2001).

2. Jeff Crisp, "No Solution in Sight: The Problem of Protracted Refugee Situations in Africa," New Issues in Refugee Research, Working Paper No. 75 (Geneva: UNHCR, January 2003) at 1.

3. Ibid. at 2; among the three million, Crisp identifies 450,000 Sudanese in Central African Republic (CAR), Chad, Democratic Republic of Congo (DRC), Ethiopia, Kenya, and Uganda.

4. Jozef Merkx, "Refugee Identities and Relief in an African Borderland: A Study of Northern Uganda and Southern Sudan," New Issues in Refugee Research, Working Paper No. 19 (Geneva: UNHCR, 2000). 
5. G. Kibreab, "African Refugees," in Reflections on the Africa Refugees Problem (Trenton, NJ: African World Press, 1985).

6. Jeff Crisp, "No Solutions in Sight: The Problem of Protracted Refugee Situations in Africa" (Paper prepared for a symposium on the multidimensionality of displacement in Africa; Kyoto, Japan, November 2002).

7. Tania Kaiser, "A Beneficiary-Based Evaluation of the UNHCR Programme in Guinea" (Geneva: UNHCR Evaluation and Policy Analysis Unit, 2001) at 21.

8. Supra note 2 at 3 .

9. Article 34, Convention relating to the Status of Refugees, 28 July 1951, 189 U.N.T.S. 150 (entered into force 22 April 1954).

10. B. Harrell-Bond, "Are Refugee Camps Good for Children?" New Issues in Refugee Research, Working Paper No. 29 (Geneva: UNHCR, 2000); Milton Gordon, Assimilation in American Life (Oxford: Oxford University Press, 1964).

11. Tom Kuhlman, "The Economic Integration of Refugees in Developing Countries: A Research Model," in Economic Integration of Refugees (London: Oxford University Press, 1991); Merkx, supra note 4; Marcelo M. Suárez-Orozco, "Everything You Ever Wanted to Know about Assimilation but Were Afraid to Ask" (Fall 2000) 129 Daedalus at 11.

12. Supra note 2 at 26.

13. For a discussion of issues of immigrant incorporation in transnational communities, see Stephen Castles, "Transnational Communities: A New Form of Social Relations under Conditions of Globalization?" in Jeffrey G. Reitz, ed., Host Societies and the Reception of Immigrants (San Diego: Center for Comparative Immigration Studies, University of California San Diego, 2003) 429-45.

14. Supra note 11; also, John Sorenson, “An Overview: Refugees and Development" in Adelman and Sorenson, eds., African Refugees: Development Aid and Repatriation (Boulder, CO: Westview Press, 1994).

15. Notable exceptions are Beth Elise Whitaker, "Changing Opportunities: Refugees and Host Communities in Western Tanzania," New Issues in Refugee Research, Working Paper No.11 (Geneva: UNHCR, June 1999); Tom Kuhlman, Burden or Boon? A Study of Eritrean Refugees in the Sudan (Amsterdam: Free University Press, 1990).

16. B.E. Harrell-Bond, Imposing Aid:Emergency Assistance to Refugees (Oxford: Oxford University Press, 1986) at 7.

17. Ibid. at 7 .

18. Supra note 11.

19. Gaim Kibreab, "Local Settlements in Africa: A Misconceived Option?” (1989) 2 Journal of Refugee Studies at 473.

20. See, among others, Karen Jacobsen, supra note 1; Tania Kaiser, supra note 7; Jeff Crisp, supra note 2; Barbara Harrell-Bond, "Toward the Economic and Social 'Integration' of Refugee Populations in Host Countries in Africa" (Paper presented at a conference organized by the Stanley Foundation, "Refugee Protection in Africa: How to Ensure Security and Development for Refugees and Hosts," Entebbe, Uganda, November 2002).
21. "Refugee Statistics as of End of December 2002" (UNHCR BO-Kampala, December 2002).

22. "Urban Refugees," Refugee Law Project, Working Paper No. 6 (Kampala: Refugee Law Project, July 2002).

23. Personal communication with Douglas Asiimwe, Office of the Prime Minister, Directorate for Refugees (5 November 2002); Personal communication with Ebende S. Lomingo, Chairman, Congolese Refugees Development Association (COREDA) (19 November 2002); Alison Parker, "Hidden in Plain View: Refugees Living without Protection in Nairobi and Kampala" (New York: Human Rights Watch, 21 November 2002).

24. Louise Pirout, "Refugees in and from Uganda in the Post Colonial Period" in Uganda Now (Nairobi: Heinemann, 1988.)

25. A.G.G. Gingyera-Pincywa, "Uganda's Entanglement with the Problem of Refugees in Its Global and African Contexts" in Uganda and the Problem of Refugees (Kampala: Makerere University Press, 1988).

26. Abraham Kiapi, "The Legal Status of Refugees in Uganda: A Critical Study of Legislative Instruments," in A.G.G. Gingyera-Pincywa, ed., Uganda and the Problem of Refugees (Kampala: Makerere University Press, 1998) at 49.

27. Yolamu Rufunda Barongo, "Problems of Integrating Banyarwanda Refugees among Local Communities in Uganda: A Study of Refugee Settlements in Hoima and Kabarole Districts," in A.G.G. Gingyera-Pincywa, ed., Uganda and the Problem of Refugees (Kampala: Makerere University Press, 1998) 117-40; Dixon Kamukama, Rwanda Conflict: Its Roots and Regional Implications (Kampala: Fountain Publishers, 1997) 33-43; V. Bond, "Identity Crisis: Banyarwanda Refugees in Uganda” (M.A. Dissertation, University of Edinburgh and Makerere University, 1998) [unpublished].

28. As Abraham Kiapi states in his article "The Legal Status of Refugees in Uganda: A Critical Study of Legislative Instruments": "The study shows that officials do not follow the Act to the letter. It is mainly applied to spontaneous refugees who enter the country in large numbers. Otherwise refugees enjoy the rights enumerated in the international instruments;" supra note 26.

29. One hundred and eighty refugees were registered on the urban caseload of UNHCR as of December 2002. Refugees become part of this caseload due to medical emergencies that require treatment in Kampala or severe security issues that make life in a settlement impossible. Although this number fluctuates, it is estimated by Inter-Aid, the implementing partner of UNHCR for the urban caseload, to be consistently around 200 refugees. Personal communication with Scholastica Nasinyama, Inter-Aid (18 November 2002).

30. Refugee Statistics as of end of December 2002, UNHCR Public Information Office.

31. It is impossible to estimate accurately how many self-settled refugees there are in Uganda. As Barbara Harrell-Bond writes, "Everyone who can gets out of them [camps and settlements] as quickly as possible. This is why there are almost always more refugees living among their hosts outside of camps;" supra note 10 . 
32. For a more detailed account of self-settled refugees, see Lucy Hovil, "Free to Go, Free to Stay? Movement, Seclusion and Integration of Refugees in Moyo District," Refugee Law Project, Working Paper No. 4 (Kampala: Refugee Law Project, 2002).

33. Supra note 4.

34. The authors would claim that the difference between camps and settlements in this context is nothing but an "operational myth.” See Liisa H. Malkki, Purity and Exile: Violence, Memory, and National Cosmology among Hutu Refugees in Tanzania (London: University of Chicago Press, 1995); Anna Schmidt, “How Camps Became 'Mainstream' Policy for Assisting Refugees" (Paper reporting on research undertaken as part of the EU-funded INCO-DC project on refugee health and welfare in Sub-Saharan Africa, London School of Economics, 1998).

35. "Strategy Paper: Self Reliance for Refugee Hosting Areas in Moyo, Arua, and Adjumani Districts, 1999-2005” (Uganda: Office of the Prime Minister/UNHCR, 1999) at 12.

36. Supra note 32. Also, for further discussion of the lack of land in Nakivale settlement, see Emmanuel Bagenda, Angela Naggaga, and Elliott Smith, "Land Problems in Nakivale Settlement and the Implications for Refugee Protection in Uganda" Refugee Law Project, Working Paper No. 8 (Kampala: Refugee Law Project, May 2003).

37. See Tania Kaiser, "UNHCR's Withdrawal from Kiryandongo: Anatomy of a Handover" (2002) 21 Refugee Survey Quarterly 201-27.

38. E. Werker, "Refugees in Kyangwali Settlement: Constraints on Economic Freedoms," Refugee Law Project, Working Paper No. 7 (Kampala: Refugee Law Project, 2002).

39. Supra note 32.

40. Supra note 32.

41. Supra note 16 at 370 .

42. Supra note 35.

43. Ibid. at 2 .

44. Ibid. at 2 .

45. Dorothy Jobolingo, UNHCR Education Advisor, at UNHCR Community Services/Education Coordination Meeting, Entebbe (1 April 2003).

46. Supra note 35 at 8.

47. Supra note 35 at 2 .

48. Supra note 35 at 9 . In addition, the SRS emphasizes that UNHCR will maintain its primary international mandate to protect refugees, and will keep a presence in districts where there is a "sufficiently large presence of refugees."

49. Supra note 35 at 8 .

50. This issue is discussed further in Section 5.

51. Supra note 35 at 11-12.

52. A most extreme case is the Achol-Pii Refugee Settlement in Pader District, Uganda. In July 1996, the Lords Resistance Army (LRA) attacked the settlement, killing over 100 unarmed refugees and wounding several others. After a passionate appeal to government to relocate them to the southern parts of the country, refugees received a response from the Government of Uganda ( $\mathrm{GoU})$, stating that they had no right to decide where to be housed and that if they were tired of government's hospitality, they should go back to their country of origin. Unable to return to Sudan, the majority remained in AcholPii. Despite numerous reports warning of an imminent attack on the settlement in 2002, the government did not act. On 5 August 2002, the LRA again attacked Achol Pii Refugee Settlement, killing more than twenty refugees, injuring several others, and displacing 23,000. See L. Hovil and A. Moorehead, "War as Normal: The Impact of Violence on the Lives of Displaced Communities Living in Pader District, Northern Uganda," Refugee Law Project, Working Paper No. 5 (Kampala: Refugee Law Project, 2002).

53. Supra note 35 at 15.

54. See also description of the SRS in Jozef Merkx, supra note 4.

55. Supra note 35 at 38.

56. Supra note 35 at 38 .

57. Supra note 35 at 39.

58. This reluctance by donors is highlighted as one of the constraints within the educational sector in the UNHCR Uganda Country Plan; obtained from Linnie Kesselly, Senior Community Service/Education Coordinator.

59. Personal communication with Linnie Kesselly, Senior Community Services/Education Coordinator, UNHCR Uganda (6 November 2002).

60. Ronald Mayanga, Refugee Desk Officer, Mbarara, UNHCR Community Services/Education Coordination Meeting, Entebbe (1 April 2003).

61. Personal communication with George Bomera, Assistant Commandant, Kyaka II Refugee Settlement (25 March 2003). Personal communication with Charles Mugisa, Assistant Education Officer, Kyenjojo District (8 April 2003). Michael Tindikira, Inspector of Schools, Bukanga Country (5 May 2003).

62. Technical Committee for Education Integration (OPM, Directorate of Refugees; Ministry of Finance, Planning and Economic Development; Ministry of Education and Sports; and UNHCR), "Consultative Workshop for Integration of Education Service Delivery, 13-14 February 2001: Draft Report, April 2001," at 3.

63. Ibid. at 27.

64. Supra note 35 at 39.

65. Technical Committee for Education Integration (OPM, Directorate of Refugees; Ministry of Finance, Planning and Economic Development; Ministry of Education and Sports; and UNHCR). "Consultative Workshop for Integration of Education Service Delivery, 13-14 February 2001: Draft Report, April 2001," at 27.

66. Personal communication with Francis Agula, Responsible for Francophone education, Uganda Ministry of Education and Sport (16 April 2003).

67. Supra note 59.

68. Interview, Jacques Bwira, Headmaster at KURCEC, Kampala (25 November 2002).

69. Field research was carried out in Moyo district from 3 to 13 February 2002. Also see Hovil, supra note 32.

70. Eric Werker, "Refugees in Kyangwali Settlement: Constraints on Economic Freedom," Refugee Law Project, Working Paper 
No. 7 (Kampala: Refugee Law Project, November 2002); online: http://www.refugeelawproject.org.

71. Interview with self-settled refugee, Moyo town (5 February 2002).

72. Supra note 35 at 32 .

73. A brief background of Universal Primary Education in Uganda: Major educational reforms began in Uganda in the late 1970s when an Education Review Committee under Idi Amin Dada proposed the introduction of Universal Primary Education (UPE) over a period of fifteen years. Another commission on education was created by Milton Obote in 1980 . In 1988 the government instituted another education review commission led by then Vice Chancellor of Makerere University, Kampala, Professor Kajubi. But it was not until 1996, during the heat of the presidential election campaign, that a program of Universal Primary Education was given serious thought by the Government. In January 1997, UPE was finally introduced, this time under the National Resistance Movement (NRM) government. This program exempts four children per family from paying primary school fees. The number of children enrolled in primary school increased that year from 2.6 million to 5.5 million. By 1999, 6.5 million children were enrolled in primary school in Uganda, equivalent to a net enrolment rate of 85 per cent. The existence of UPE does not mean that primary school education in Uganda is completely free. Parents or guardians must often support the cost of school buildings, books, writing materials, school meals, and uniforms. The result has been the development of schools that - while licensed by the government and receiving government aid for teachers' salaries - do charge school fees, which are prohibitive for many families, especially in urban areas. At these schools, the school fees pay for construction of new school buildings, the hiring of teachers to decrease the pupilteacher ratio, and the expansion of recreational and technology programs. In addition, the quality of education at UPE primary schools that do not charge school fees - and are therefore accessible to most families - is low. There are insufficient schools, classrooms, and trained teachers for the influx of pupils who have joined primary school since the introduction of UPE in 1997. Indeed, for every permanent classroom in Uganda, there are on average 228 pupils. As concluded in a study of the ActionAid-Uganda/Centre for Basic Research, "UPE has improved children's access to classroom buildings but not to quality primary education."

74. Supra note 35 at 32 .

75. Interview, George Bomera, assistant camp commandant, Kyaka II refugee settlement (25 March 2003). Kyaka II refugee settlement was regazetted in 1994 after the repatriation of Rwandese refugees. At this time the area of the settlement decreased from 220 square kilometres to 81 square kilometres.

76. "Refugee Statistics as of End of December 2002" (UNHCR Kampala, December 2002.).

77. See: Yolamu Rufunda Barongo, supra note 27 at 118-22.

78. "Refugee Life," a broadcast of Common Ground (11 March 1997).

79. Interview, Charles Mugisa, Inspector of Schools Kyaka County, Kampala (4 April 2003).
80. Charles Mugisa, Inspector of Schools Kyaka County, at UNHCR Community Services/Education Coordination Meeting, Entebbe (1 April 2003).

81. Personal communication with Imedla Atwooki, Coordinator of Community Services/Education for OPM, Kyaka II refugee settlement (25 March 2003).

82. Interview, Douglas Asiimwe, DEO Kyenjojo District, Kampala (25 April 2003).

83. One of the primary purposes of education in a refugee situation is the creation of stability for children coming from situations of conflict and displacement. As stated in the UNHCR "Education Sector Policy and Guidelines," "[e]ducation helps meet psychosocial needs.... Crisis situations involving conflict and displacement cause disruption of children's lives, the break up of families and social ties, and uncertainty regarding their futures." From UNHCR, Education Sector Policy and Guidelines (Draft) (Geneva: UNHCR, 2002).

84. The Batooro people traditionally live in the Toro Kingdom area of Kabarole and Kasese districts.

85. From the Ugandan school anthem.

86. Personal observation in P.5 class, Bujubuli Primary School, Kyaka II refugee settlement (24 March 2003).

87. Interviews with Bujubuli nationals, Bujubuli Primary School, Kyaka II refugee settlement (27 March 2003).

88. Personal observation, Bujubuli Primary School, Kyaka II refugee settlement, and Kabweeza Primary School, Kyaka County (7 March to 10 April 2003).

89. Classroom observations, Bujubuli Primary School, Kyaka II refugee settlement (24, 25, and 26 March 2003).

90. "Poverty Eradication Action Plan (2001-2003)," Volume 1 (Kampala: Government of Uganda, Ministry of Finance, Planning and Economic Development, February 2001) at 1.

91. Ibid. at 10 .

92. Ibid. at $4-5$.

93. Ibid. at 1.

94. Warren Nyamugasira, "Monitoring of the Poverty Eradication Action Plan (PEAP)" (A presentation at the Consultative Workshop on the Revision of the PEAP and Public Expenditure Review, Kampala International Conference Centre, May 15-16, 2000.)

95. It falls beyond the scope of this paper to analyze the successes and failures of the PEAP.

Sarah Dryden-Peterson is an Ed.D. Candidate at the Harvard Graduate School of Education and research associate of the Refugee Law Project of Makerere University, Uganda (www.refugeelawproject.org).

Dr. Lucy Hovil is Senior Research and Advocacy Officer with the Refugee Law Project, Faculty of Law, Makerere University, Uganda. 